\title{
VIP wt Allele
}

National Cancer Institute

\section{Source}

National Cancer Institute. VIP wt Allele. NCI Thesaurus. Code C52433.

Human VIP wild-type allele is located in the vicinity of $6 q 25$ and is approximately $9 \mathrm{~kb}$ in length. This allele, which encodes VIP peptides protein, is involved in the modulation of calcium levels. The gene is expressed aberrantly in some breast cancers. 